\title{
PENGARUH MOTIVASI KERJA TERHADAP KINERJA KARYAWAN DALAM SUATU PERUSAHAAN/ORGANISASI
}

\author{
Oleh: Weni yunarsih
}

\section{UNIVERSITAS NEGERI PADANG}

\author{
Email: weniyunarsh@gmail.com
}

\begin{abstract}
ABSTRAK
Artikel ini bertujuan untuk mengetahui pengaruh motivasi kerja terhadap kinerja karyawan. Motivasi bertujuan untuk meningkatkan dan memajukan kinerja karyawan dalam dunia pekerjaan, oleh sebab itu motivasi kerja pada sebuah perusahaan/organisasi merupakan suatu hal yang perlu untuk dipelajari dan menarik untuk diteliti.

Dengan adanya motivasi kerja membuat karyawan menjadi semangat dalam bekerja. Manajemen modern berpendapat, bahwa tingkah laku manusia didorong oleh motif-motif tertentu, dan perbuatanl/bekerja akan berhasil bila didasarkan pada motivasi yang ada.

motivasi kerja berpengaruh signifikan terhadap kinerja karyawan. Secara parsial motivasi kerja berpengaruh secara signifikan terhadap kinerja karyawan. karyawan disarankan untuk dapat menjalin hubungan baik dengan rekan kerja. Khususnya dalam meningkatkan interaksi dengan orang lain, Sehingga apabila terdapat masalah dalam pekerjaan diharapkan untuk mendiskusikan segala keputusan dengan rekan kerja lainnya terlebih dahulu. karyawan juga disarankan untuk dapat menyesuaikan diri dengan rekan kerja lain apapun sifat dan wataknya dan disarankan untuk menghargai karyawan lainnya dalam melaksanakan pekerjaan.
\end{abstract}

Kata Kunci: Motivasi Kerja, Kinerja Karyawan 


\section{PENDAHULUAN}

\section{LATAR BELAKANG}

Motivasi sangat penting dalam dunia kerja atau organisasi untuk dianalisis motivasi karyawan diperlukan agar mereka dapat menyelesaikan tugas yang diberikan dengan baik. Menurut Marwansyah (2010:116), menyatakan bahwa "motivasi adalah sesuatu yang menimbulkan semangat atau dorongan kerja". Diperkuat dengan pernyataan dari Robbins dalam jurnal Zunaidah dan Budiman (2014:45) menyatakan bahwa motivasi sebagai proses yang menjelaskan intensitas, arah dan ketekunan seseorang individu untuk mencapai tujuannya

Kinerja karyawan dapat dipengaruhi oleh motivasi yang diterapkan dalam perusahaan bersangkutan. Dan di dalam organisasi juga berpengaruh. Nilai-nilai perusahaan dan oganisasi tersebut merupakan salah satu bentuk motivasi untuk meningkatkan kinerja karyawan (Zunaidah dan Budiman,2014:46). Adanya penurunan motivasi berpengaruh terhadap kinerja hal ini membuktikan bahwa adanya hubungan antara motivasi dengan kinerja.

Tingkat motivasi sangat berhubungan dengan kinerja karyawan. Oleh karena itu, organisasi harus memotivasi karyawan mereka untuk kinerja terbaik untuk mencapai tujuan organisasi. Dikutip dari jurnal internasional menurut Zameer et.al (2014:293). Hal ini didukung oleh Menurut McClelland et.al. dalam jurnal Zunaidah dan Budiman (2014:49) menyatakan bahwa ada hubungan antara motivasi dan berprestasi dengan pencapaian kinerja. Artinya, pimpinan, manajer dan pegawai yang mempunyai motivasi berprestasi tinggi akan mencapai kinerja tinggi, dan sebaliknya mereka yang kinerjanya rendah disebabkan karena motivasi kerjanya rendah. (Mangkunegara, 2009:67), kinerja karyawan adalah hasil kerja secara kualitas dan kuantitas yang dicapai oleh seorang pegawai dalam melaksanakan tugasnya sesuai dengan tanggung jawab yang diberikan kepadanya. Standar pekerjaan dapat ditentukan dari isi suatu pekerjaan, dapat dijadikan sebagai dasar penilaian setiap pekerjaan (Bangun, 2012:233). 
Di dalam upaya mencapai tujuan tersebut, perlu adanya suatu faktor yang harus dimiliki oleh para pegawai, yakni semangat kerja. Semangat kerja itu sendiri timbul dan tumbuh dalam diri pegawai yang disebabkan adanya motivasi dari pimpinan dalam arti pimpinan memberi motif atau dorongan kepada pegawai, di mana motif itu sendiri menyangkut pada kebutuhan pegawai, baik kebutuhan batin maupun kebutuhan lahir.

Tujuan pembuatan artikel ini adalah untuk mengetahui pengertian motivasi kerja dan kinerja karyawan (prestasi kerja) dan bagaimana pengaruh motivasi kerja terhadap kinerja karyawan dalam suatu perusahaan. 


\section{PEMBAHASAN}

\section{Pengertian motivasi kerja}

Terdapat beberapa pengertian motivasi dari beberapa ahli seperti yang diungkapkan oleh Hasibuan dalam Sunyoto (2012:191), motivasi berasal dari kata lain movere yang berarti dorongan atau daya penggerak motivasi ini hanya diberikan kepada manusia, khususnya kepada para bawahan atau pengikut. Menurut Mangkunegara (2009:93), motif merupakan suatu dorongan kebutuhan dalam diri pegawai yang perlu dipenuhi agar pegawai tersebut dapat menyesuaikan diri terhadap lingkungannya, sedangkan motivasi adalah kondisi yang menggerakkan pegawai agar mampu mencapai tujuan dari motifnya. Motivasi dapat pula dikatakan sebagai energi untuk membangkitkan dorongan dalam diri (drive arousal). Menurut Marwansyah (2010:116), menyatakan bahwa "motivasi adalah sesuatu yang menimbulkan semangat atau dorongan kerja".(Lathofah and Wahjuadi 2015)

"Motivasi adalah suatu perubahan energi dalam diri (pribadi) seseorang yang ditandai dengan timbulnya perasaan dan reaksi untuk mencapai tujuan." (Lathofah and Wahjuadi 2015)

Menurut jurnal Zunaidah dan Budiman (2014:48), dalam motivasi terdapat beberapa teori yang dikemukakan oleh para ahli seperti McClelland, Maslow, Herzberg dan McGregor. Teori motivasi tiga kebutuhan dikemukankan oleh McClelland, teori ini berfokus pada tiga kebutuhan: pencapaian (achievement), kekuatan (power) dan hubungan (affiliation) (Robbins,2008:230). (Lathofah and Wahjuadi 2015)

(Mangkunegara, 1993) Teori berikutnya yaitu teori jenjang kebutuhan, dikemukakan oleh Maslow ini menyatakan bahwa untuk memotivasi karyawan pihak manajemen perusahaan harus mampu memenuhi kebutuhan-kebutuhan karyawan. Menurut Maslow, manusia akan didorong untuk memenuhi kebutuhan yang paling kuat sesuai waktu, keadaan dan pengalaman yang bersangkutan mengikuti suatu hirarki (Handoko, 2009:256). Susunan tingkat kebutuhan-kebutuhan tersebut meliputi: 1) kebutuhan fisik, 2) kebutuhan keamanan yang diperlukan bagi 
berlanjutnya pemenuhan kebutuhan-kebutuhan fisik dan keamanan psikologis, 3) hak memiliki dan kebutuhan akan cinta kasih, 4) kebutuhan-kebutuhan harga diri, 5) kebutuhan akan aktualisasi diri. Teori berikutnya diungkapkan oleh Herzberg. Herzberg membaginya dalam dua faktor yaitu faktor hygiene dan faktor motivator. Pertama, adalah yang disebut hygiene factors, yaitu ada atau tidaknya ketidakpuasan kerja (job dissatisfiers) seperti kualitas pengawasan, imbalan kerja, kebijaksanaan perusahaan, kondisi fisik pekerjaan, hubungan dengan individu lain dan keamanan pekerjaan (Robbins, 2008:227). Faktor motivator (motivators) merupakan faktorfaktor yang berhubungan dengan pekerjaan itu sendiri atau dengan hasil-hasil yang berasal darinya - seperti peluang promosi, peluang pengembangan diri, pengakuan, tanggung jawab dan pencapaian (Robbins, 2008:228). Motivasi terbagi menjadi 2 yaitu:

1. Motivasi intrinsik, yaitu motivasi dari dalam diri seseorang; seseorang melakukan sesuatu karena ia ingin melakukannya.

2. Motivasi ekstrinsik adalah motivasi yang berasal dari luar diri seseorang. Seseorang melakukan sesuatu untuk memenangkan suatu hadiah yang khusus ditawarkan untuk perilaku tersebut.

Ada dua prinsip yang dapat digunakan untuk meninjau motivasi, ialah:

1. Motivasi dipandang sebagai suatu proses. Pengetahuan tentang proses ini akan membantu kita menjelaskan kelakuan yang kita amati dan untuk memperkirakan kelakuan-kelakuan lain orang tersebut.

2. Kita menentukan karakter dari proses ini dengan melihat petunjukpetunjuk yang tampak tingkah lakunya.

Motivasi yang tinggi dalam diri seseorang ditandai dengan munculnya keinginan untuk memperoleh hasil kerja yang memuaskan dalam melaksanakan pekerjaan, karena dengan motivasi kerja guru akan berupaya memperoleh prestasi kerja, memiliki tanggung jawab dalam melaksanakan tugas dan selalu mencari inovasi baru.(Ermita 2019) 


\section{Pengertian kinerja karyawan (prestasi kerja)}

Menurut Mangkunegara (2006:9) dalam jurnal (Lathofah and Wahjuadi 2015) "Kinerja Karyawan (prestasi kerja) adalah hasil kerja secara kualitas dan kuantitas yang dicapai oleh seorang karyawan dalam melaksanakan tugasnya sesuai dengan tanggung jawab yang diberikan kepadanya”. Kemudian menurut Maluyu S.P. Hasibuan (2001:34) mengemukakan: "kinerja (prestasi kerja) adalah suatu hasil kerja yang dicapai seseorang dalam melaksanakan tugas tugas yang dibebankan kepadanya yang didasarkan atas kecakapan, pengalaman dan kesungguhan serta waktu". Indikator kinerja adalah :

1. Kompetensi individu yaitu dari kemampuan dan keterampilan kerja seorang karyawan dalam melaksanakan tugas yang diberikan kepadanya. kemampuan atasan dalam memberikan motivasi.

2. Dukungan organisasi yaitu seperti tersedianya sarana dan prasarana kerja serta kenyamanan lingkungan.

3. Dukungan manajemen yaitu seperti sikap kepemimpinan masing-masing pimpinan.

4. Faktor internal yang dihubungkan dengan sifat dan watak seseorang.

5. Faktor Eksternal yaitu faktor kinerja yang dipengaruhi dari lingkungan seperti tindakan-tindakan rekan kerja, bawahan atau pimpinan dan iklim kerja.

\section{Faktor - Faktor yang Mempengaruhi Kinerja}

Menurut Timpe (1993) faktor - faktor yang mempengaruhi kinerja, yaitu:

1.Kinerja baik dipengaruhi oleh dua faktor :

a. Internal (pribadi)

- kemampuan tinggi

- kerja keras

b. Eksternal (lingkungan)

- pekerjaan mudah

- Nasib baik

- bantuan dari rekan-rekan 
- pemimpin yang baik

2. Kinerja jelek dipengeruhi dua faktor:

a. internal (pribadi)

- kemampuan rendah

- upaya sedikit

b. eksternal (lingkungan)

- pekerjaan sulit

- Nasib buruk

- rekan-rekan kerja tidak produktif

- $\quad$ pemimpin yang tidak simpatik

Penilaian prestasi kerja adalah:

1. Manajer menilai prestasi kerja karyawan dengan maksud agar mengetahui mana karyawan-karyawan yang lebih baik

2. Manajer menilai prestasi kerja karyawan dengan maksud agar mereka dapat memberikan hadiah atas prestasi atas prestasi kerja yang baik.

3. Manajer menilai prestasi kerja karyawan untuk mendorong karyawan agar bekerja dengan baik.

Kinerja pegawai tidak hanya sebagai hasil kerja yang telah dicapai oleh seorang pegawai dalam suatu organisasi, namun kinerja juga merupakan suatu proses bagaimana pekerjaan pegawai tersebut berlangsung sehingga mencapai hasil kerja yang diharapkan. Sebagaimana yang dijelaskan oleh wibowo (2012) kinerja bukan hanya hasil, tetapi termasuk proses pekerjaan berlangsung.(Ermita and Rahmayani 2019) 


\section{Pengaruh motivasi kerja terhadap kinerja karyawan dalam suatu perusahaan/organisasi}

Motivasi adalah hasrat untuk berupaya guna memberikan manfaat bagi orang lain ( Grant, 2008a dalam jurnal of Applied Psychology, 93, 48 - 58 ) menunjukkan tingkat dimana perilaku para karyawan berhasil di dalam memberikan kontribusi tujuantujuan organisasi ( Motowidlo, 2003 dalam jurnal Applied Psychology ). karyawan akan lebih memiliki keyakinan terhadap komunikasi misi dan tindakan para manajer yang dapat dipercaya. Ini akan memungkinkan karyawan untuk melihat bagaimana pekerjaan mereka membantu pihak yang menerima manfaat serta meningkatkan kinerja karyawan. 27 Selain itu lingkungan kerja juga tidak kalah pentingnya di dalam pencapaian kinerja karyawan. Dimana lingkungan kerja mempengaruhi karyawan dalam menyelesaikan pekerjaannya. Dengan adanya lingkungan kerja yang memadai tentunya akan membuat karyawan betah bekerja, sehingga akan timbul semangat kerja dan kegairahan kerja karyawan dalam melakasanakan pekerjaannya, kinerja karyawan akan meningkat. Sedangkan lingkungan kerja yang tidak memadai dapat mengggangu konsentrasi karyawan dalam melaksanakan pekerjaaannya sehingga menimbulkan kesalahan dalam bekerja dan kinerja karyawan akan menurun.

Jadi hubungan motivasi kerja sangat berpengaruh terhadap kinerja karyawan. Sesuai dengan pendapat suharsimi (1993) dan suhertian (1994) yang mengatakan bahwa faktor motivasi seseorang akan mempengaruhi pelaksanaan tugas atau kinerja yang dilakukannya.(Ermita 2019) 


\section{PENUTUP}

\section{A. Kesimpulan}

Dalam artikel ini kesimpulan yang dapat diambil adalah:

1. Motivasi kerja sangat berpengaruh terhadap kinerja pegawai, dengan adanya motivasi kerja maka karyawan akan lebih memiliki keyakinan dalam bekerja.

2. Kinerja karyawan juga sangat berpengaruh terhadap suatu pekerjaan, dengan adanya kinerja atau prestasi kerja maka karyawan akan semangat dalam bekerja.

3. Pengaruh motivasi dan kinerja karyawan dalam suatu perusahaan adalah dengan adanya motivasi kerja membuat karyawan menjadi lebih semangat bekerja, dan natinya akan berdampak baik terhadap pekerjaan dan nantinya akan mendapatkan reward yaitu prestasi terhadap kinerja karyawan tersebut.

\section{B. Saran}

Berdasarkan kesimpulan yang diperoleh dari artikel pengaruh motivasi kerja terhadap Kinerja Karyawan, maka penulis mempunyai beberapa saran antara lain sebagai berikut:

1. Motivasi harus lebih ditingkatkan lagi dalam suatu perusahaan, karena dapat berpengaruh terhadap kinerja pegawai.

2. Kinerja karyawan atau prestasi kerja harus diberikan oleh manajer kepada karyawan, agar karyawan menjadi lebih semangat dalam bekerja dan tujuan dalam suatu pekerjaan tersebut dapat tercapai

3. Motivasi dan kinerja pegawai sangat berpengaruh, untuk itu harus ditingkatkan lagi agar memiliki dampak yang baik bagi karyawan itu sendiri. 


\section{Daftar Pustaka}

Ermita. 2019. "Kontribusi Gaya Kepemimpinan Kepala Sekolah Dan Motivasi Kerja Terhadap Kinerja Guru Di Sekolah Menengah Atas Negeri (SMAN) Kecamatan Koto Tangah Kota Padang." HIJRI, Jurnal Manajemen Pendidikan dan Keislaman 8(1): 107-23.

Ermita, and Mira Rahmayani. 2019. "Pembinaan Kinerja Pegawai Oleh Pimpinan Atasan Langsung Di Kantor Kementerian Agama Kota Bukittinggi.” Bahana Manajemen Pendidikan 8(3): 278-85.

Lathofah, Alis, and Djoko Wahjuadi. 2015. "Pengaruh Motivasi Kerja Terhadap Kinerja Karyawan Pada PT. Saluyu Prima Group.” : 1-8.

Mangkunegara, A. P. (1993). Psikologi Perusahaan. Bandung: Trigenda Karya. 